\title{
ABOUT FINDING NATIVE GOLD, SILVER, COPPER, LEAD, BISMUTH AND TUNGSTEN IN LIPOVKA PEGMATITES (MIDDLE URAL)
}

\author{
Anatoliy Vladimirovich Zakharov, \\ zakharov-zav@yandex.ru \\ Vera Vital'evna Khiller \\ hilvervit@mail.ru
}

\author{
Zavaritsky Institute of Geology and Geochemistry \\ of the Ural Branch of the Russian Academy of Sciences \\ Ekaterinburg, Russia
}

\begin{abstract}
The relevance of the work is conditioned by the need for a more complete study of the mineralogy of rare-metal granite pegmatites of the Lipovskoye vein field.

The purpose of the study is to describe the findings of native metals (gold, silver, copper, lead, bismuth and tungsten) in granite pegmatites of the Lipovskoye vein field.

Research methodology. Detailed study of chemical composition, morphology and relationships of native metals with associated minerals. For this study we have chosen samples from the three types of granitic pegmatites - classical quartz-feldspar (mostly intragranitic), desilicated (apogranite plagioclasite) and contaminated lithium-bearing.

Results. The paper describes native metals (gold, silver, copper, lead, bismuth and tungsten), which we have found in rare-metal pegmatites of the Lipovskoye vein field. The discovery of the native metals is the first on this facility. The microprobe analysis of such native metals as gold and silver showed the variability of their chemical composition from the type of pegmatite in which they are present. The formation of native lead should be logically linked to the destruction and recrystallization of high uranium thin rims of zircons. The formation of bismuth and tungsten may have occurred during recrystallization of accessory tantalumniobates.

Summary. The finding of the native metals in granitic pegmatites is quite explainable. This is because these core rocks are formed in the post-magmatic stage of the silicate crystallization intrusions and they can contain typomorphic rocks for these metals. The absence of mineral concentrators (sulfides) in pegmatites clearly explains the small size and high dispersion of metals.
\end{abstract}

Keywords: native metals; ore mineralization; granite pegmatites; Lipovskoye vein field; Middle Urals.

ntroduction

The pegmatites of the Lipovskoye vein field lie in different rocks (gneisses, serpentinites, marbles, amphibolites, etc.) between the three granite massifs - Murzinsky, Aduisky and Sokolovsky. The geological structure of the area is a zone of mélange. In this zone, the bodies of serpentinites, gneisses, amphibolites and marbles are tectonically interspersed with each other in the form of separate blocks. Granitic pegmatites are represented by three metal types: classical quartz-feldspar (intragranitic), desilicated (apogranite plagioclasite) and contaminated lithium-bearing [1].

In this paper, we have described native metals (gold, silver, copper, lead, bismuth and tungsten), which we have found in rare metal pegmatites of the Lipovsky vein field. The discovery of the aforementioned minerals is the first one in this object. In the recent report on the mineralogy of granite pegmatites of Lipovka [2] there is no information about them. Previously we have published abstracts of papers about the discovery of gold, silver and copper in the Lipovka pegmatites [3].

Methods

We have investigated granitic pegmatites, which outcrop within abandoned and flooded quarries of the waste Lipovskaya silicate-nickel deposits. All native metals were discovered and investigated with the electron-probe microanalyzer CAMECA SX 100. This was performed at the Institute of Geology and Geochemistry, Ural Branch of the Russian Academy of Sciences, analyzed by V. V. Khiller. The metal phases were studied on polished sections of pegmatites. They were cut on a diamond saw, polished the face plate with abrasive powder and polished with diamond pastes and chromium oxide. All the aforementioned technology of manufacturing preparations excludes the possibility of rubbing the above mentioned metals into polished sections. The preparations have been manufactured at the Institute of Geology and Geochemistry, Ural Branch of the Russian Academy of Sciences.

Native metals in granite pegmatites of the Lipovskoye vein field

Gold. This metal was installed in ordinary quartz-K-feldspar (intragranitic) pegmatites, and also in lepidolite aggregate of lithium-bearing pegmatites. Gold does not form any intergrowths with accessory minerals and other metals, it forms isometric inclusions in the matrix of feldspar and mica. Grain size is no bigger than 10 to $15 \mathrm{ppm}$. The chemical composition of gold from different pegmatites is given in the Table 1. The metal is characterized by high purity and almost does not contain impurities. It is of great interest that gold from lepidolite aggregate has impurities in contrast to its counterpart of ordinary pegmatites, which virtually has $100 \%$ degree of purity. This

Table 1. Chemical composition of gold in Lipovka pegmatites, wt. \%.

Таблица 1. Химический состав (в мас. \%) золота в пегматитах Липовки.

\begin{tabular}{|c|c|c|c|c|c|c|}
\hline Points & $\mathrm{Zn}$ & $\mathrm{Cu}$ & $\mathrm{Au}$ & $\mathrm{Ag}$ & $\mathrm{Hg}$ & Total \\
\hline 1 & - & 0.05 & 99.87 & 0.01 & - & 99.93 \\
\hline 2 & - & 0.01 & 99.95 & - & - & 99.96 \\
\hline 3 & - & 0.50 & 98.91 & 1.24 & - & 100.65 \\
\hline 4 & - & 0.51 & 98.53 & 1.14 & - & 100.18 \\
\hline 5 & - & 0.46 & 98.17 & 1.05 & - & 99.68 \\
\hline 6 & - & 0.56 & 97.16 & 0.95 & - & 98.67 \\
\hline 7 & - & 0.57 & 97.58 & 0.93 & - & 99.08 \\
\hline
\end{tabular}

Note: analyses 1-2 - ordinary pegmatites, analyses 3-7 - lithium-bearing pegmatites. 


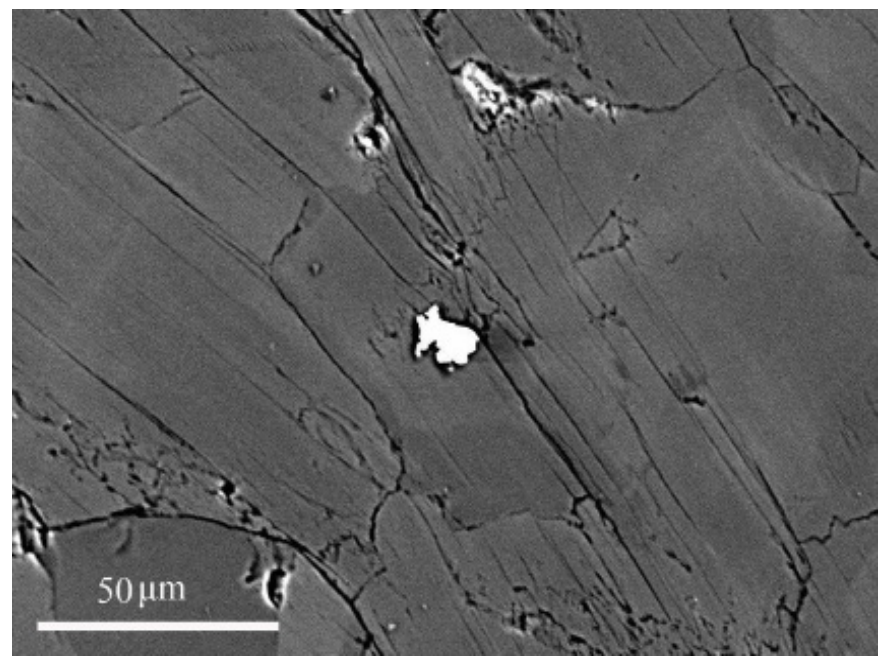

Figure 1. The inclusion of native silver in the aggregate of trilithionite. The image was made in the back-scattered electron CAMECA SX 100.

Рисунок 1. Включение самородного серебра в агрегате трилитионита. Изображение в обратных электронах, CAMECA SX 100.

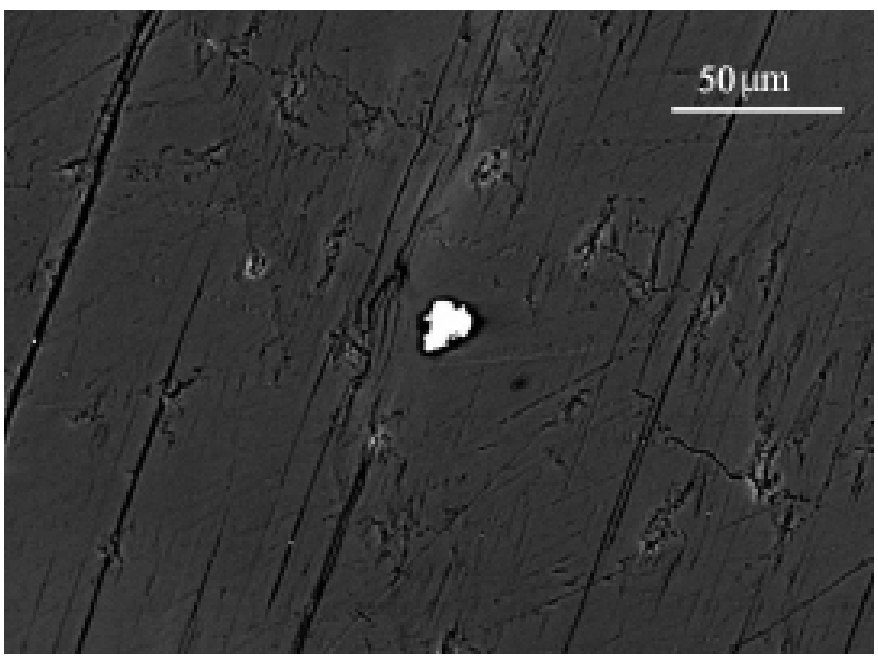

Figure 2. The inclusion of native copper in the aggregate of trilithionite. The image was made in the back-scattered electron CAMECA SX 100.

Рисунок 2. Включение самородной меди в агрегате трилитионита. Изображение в обратных электронах, CAMECA SX 100.

Table 2. Chemical composition of silver in Lipovka pegmatites, wt. \%.

Таблица 2. Химический состав (в мас. \%) серебра в пегматитах Липовки.

\begin{tabular}{cccccrrr}
\hline Points & $\mathrm{Zn}$ & $\mathrm{Cu}$ & $\mathrm{Au}$ & $\mathrm{Ag}$ & $\mathrm{Hg}$ & \multicolumn{1}{c}{ Total } \\
\hline 1 & - & - & 0.08 & 99.32 & 100.01 & - & 99.40 \\
2 & - & 0.02 & - & 98.86 & 0,12 & 100.03 \\
3 & - & 0.04 & - & - & 100.43 & 99.11 & 100.50 \\
4 & - & 0.02 & - & 99.06 & 0,16 & 99.33 \\
5 & 0.09 & - & 0,04 & 99.72 & - & 99.76 \\
6 & - & & -
\end{tabular}

Note: analysis 1 - ordinary pegmatites, analyses 2-6 - lithium-bearing pegmatites.

high purity in quite rare nature and is characteristically a feature of secondary and supergene gold [4]. It is also typical in the metal from the ore exhalation of basalts found in a Large basaltic fissure eruption of Tolbachik [5] and in the lunar regolith as well [6]. In general, the discovery of native gold in granite pegmatites is very interesting, because this metal was not described earlier in these rocks [4, 7, 8, etc.].

Silver. This metal as well as gold, is found in ordinary quartz-K-feldspar (intragranitic) pegmatites and in lepidolite aggregate of lithium-bearing pegmatites. Silver does not form any intergrowths with accessory minerals and other metals either. It consists of isometric xenomorphic grains, no more than 20-25 microns in size (Fig. 1). The chemical composition of silver from different pegmatites is given in Table 2. This metal has high purity and contains almost no impurities. Native silver, as well as gold, in granite pegmatites was not found earlier [4, 7 , etc.]. In the Urals, the silver was found in skarn, massive cupper-sulfide deposits, rhyolite, serpentinite and metamorphosed cupriferous cuprous sandstones, as well as in supergene in the zones of oxidation in different ores [4].

Copper. This metal as well as gold with silver is installed in an ordinary quartz-K-feldspar (intragranitic) and lithium-bearing pegmatites. Copper does not form any intergrowths with the accessory minerals of other metals. Grains are sprayed in all rock-forming minerals, except for quartz; their size is no more than 10-15 microns (Fig. 2). The chemical composition of copper from different pegmatites is given in Table 3 . The metal has a high purity and does not almost contain any impurities. It is worth noting, that copper is the predominant metal in ordinary pegmatites. It sharply prevails over gold and silver, while in lithium-bearing pegmatites the quantitative ratio of metals is approximately equal to each other. The findings of metallic copper in granite pegmatites were not described before $[4,7,8$, etc.]. In the Urals native copper is found in various volcanites, serpentinites, cuprous sandstones, and quartz veins, as well as in oxidation zones of various copper-containing ores [4].

Lead. This metal as well as the aforementioned copper, gold and silver, are found in an ordinary quartz-K-feldspar (intragranitic) and in lithium-bearing pegmatites. In ordinary pegmatites, it is detected as small (up to 5 microns) inclusions in the matrix of potassium feldspar. The metal is associated with grains of native gold; its microprobe analysis showed that it was only lead that was found there and the complete absence of any impurities. In the lithium-bearing pegmatites the metal occurs as small inclusions (less than 10 microns) in the metamict zircon, which underwent serious changes. This metal associates with the abundant impregnation of uraninite. The chemical composition of the inclusions is as follows, wt. \%: Pb 70.15; Sn 29.14; total 99.29. In general, the formation of native lead is quite logical to associate with the destruction and recrystallization of high-uranium zircons, which characteristically belong to the Lipovsky pegmatites. The migration of radiogenic lead from uranium minerals without their destruction in the conditions of endogenous processes at temperatures and pressures corresponding to natural conditions of metamorphism was experimentally confirmed [9]. In the Urals, lead was observed in pegmatoid aegirine-augite veins, 
Table 3. Chemical composition of copper in the pegmatites of Lipovka, wt. \%.

Таблица 3. Химический состав (в мас. \%) меди в пегматитах Липовки.

\begin{tabular}{|c|c|c|c|c|c|c|}
\hline Points & $\mathrm{Zn}$ & $\mathrm{Cu}$ & $\mathrm{Au}$ & $\mathrm{Ag}$ & $\mathrm{Hg}$ & Total \\
\hline 1 & - & 98.40 & - & 0.11 & - & 98.51 \\
\hline 2 & - & 98.46 & 0.08 & 0.08 & 0.01 & 98.62 \\
\hline 3 & 0.01 & 99.56 & - & - & 0.02 & 99.60 \\
\hline 4 & - & 98.37 & 0.03 & 0.11 & 0.10 & 98.61 \\
\hline 5 & - & 98.96 & - & 0.08 & 0.02 & 99.07 \\
\hline 6 & 0.03 & 98.04 & - & - & 0.09 & 98.16 \\
\hline 7 & 0.04 & 99.19 & 0.01 & 0.05 & 0.20 & 99.49 \\
\hline 8 & _- & 98.78 & 0.04 & _- & - & 98.82 \\
\hline
\end{tabular}

Note: analyses 1-4 - ordinary pegmatites, analyses 5-8 - lithium-bearing pegmatites.

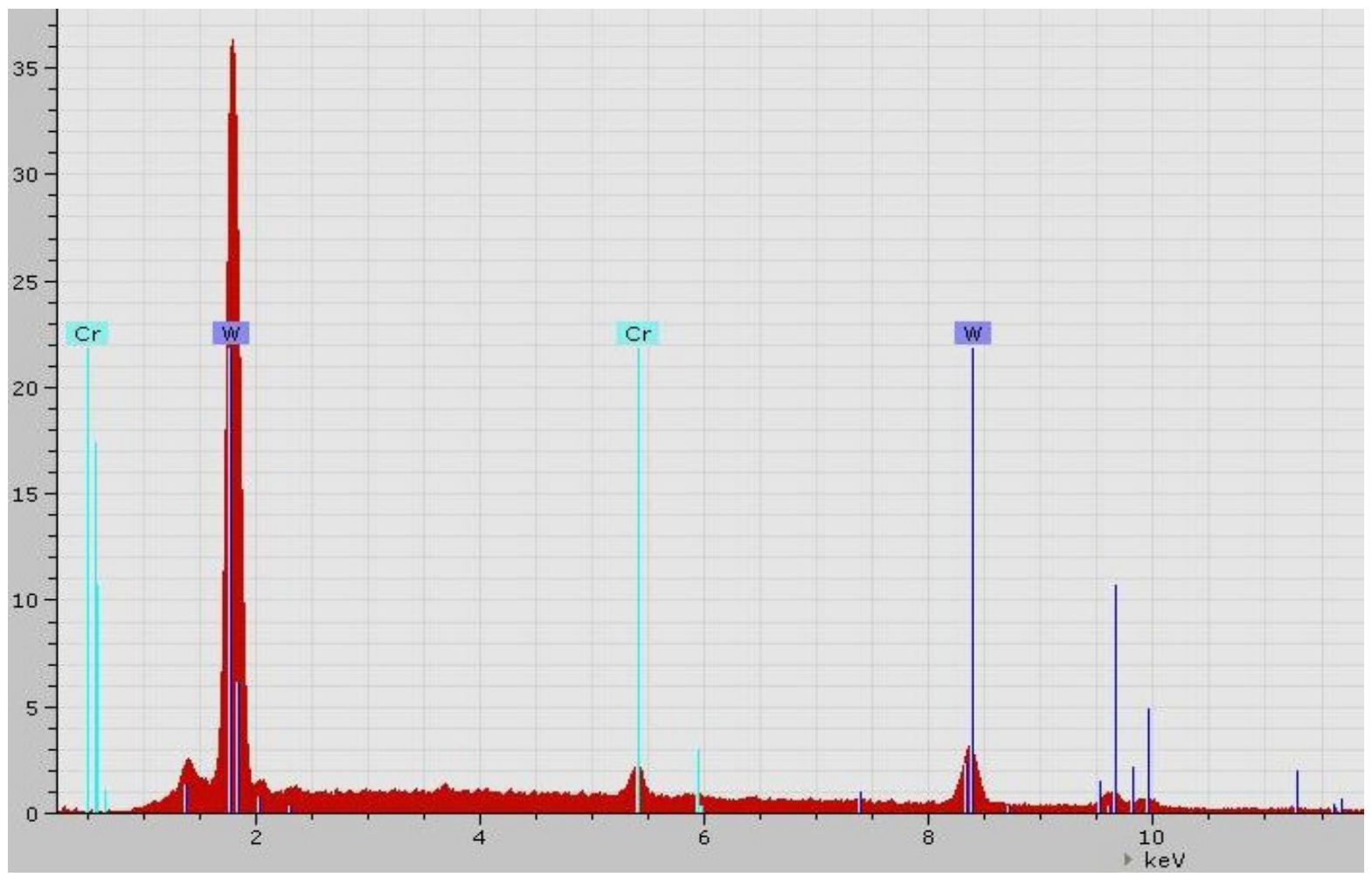

Figure 3. An energy dispersive spectrometer spectrum of tungsten from desilicated Lipovka pegmatites. Рисунок 3. ЭДС-спектр вольфрама из десилицированных пегматитов Липовки.

hydrothermal and hypergenic formations, as well as in alluvial deposits [4]. It is interesting, that hypogene lead crystallizes in a wide range of temperatures and pressures. This interval fluctuates from mantle conditions (inclusions in the black diamonds [10]) to low-temperature metasomatic rocks (smears and inclusions in pyrite from argillites [11]).

Bismuth. This metal is found in ordinary quartz-K-feldspar (intragranitic) pegmatites. It forms a rare and small (up to 5 $\mu \mathrm{m}$ ) inclusions in the feldspars, although it is quite likely to be found in the desilicated pegmatites (plagioclasites). Microprobe analysis of the inclusions showed the presence of bismuth and the complete absence of any impurities. This made it possible for us to ascribe it to the native bismuth. The mineral does not form any intergrowths with accessory minerals and other metals. It is quite logical to associate the formation of native bismuth with the recrystallization of accessory tantalumniobates. At the Lipovka pegmatites these accessory tantalumniobates are often enriched with this element. This leads to the formation of self-dependent minerals called bismutotantalite and bismutomicrolite [2]. In general, the findings of native bismuth in the Ural pegmatites are not uncommon. This metal was described in the vein plagioclazites of the Ural emerald mines [12], on the Kvartal'noye tantalum-niobium deposit [13] and on many other objects.

Tungsten. This metal was found in desilicated pegmatites (vein plagioclazites) only, where it forms a rare and small (up to 10 $\mu \mathrm{m}$ ) inclusions in the rock forming anorthite. The microprobe analysis of the inclusions showed the presence of small impurities of chromium ( $\mathrm{Cr}$ up to $4.5 \mathrm{wt}$. \%), no reflections of other elements, including carbon, are recorded (Fig. 3). This allows us to determine this phase as metallic tungsten. The mineral does not form intergrowths with accessory minerals and other metals. The formation of native tungsten is quite logical to associate with the recrystallization of accessory tantalumniobates. They are often enriched with this element in the Lipovka pegmatites [2].

In nature, tungsten is rare enough and even as a mineral species it was approved by the International Mineralogical Associ- 
ation relatively recently, in 2011 [14]. Previously, this metal was found in the alluvial deposits of the Bol'shaya Pol'ya river on the eastern slope of the Polar Urals [15]. However, the mineral was not approved until it was found in quartz veins from the nearby Dodo mine. The finds were made of native tungsten in the lunar regolith [6], the chromitites from the Polar Urals [16]. The mineral was also found in the products of exhalation from the Great fissure eruption of Tolbachik [17], in the argillite of Gumeshevsky copper mine [11] and also in many other places.

Conclusion

In general, the discovery of native metals in granite pegmatites is quite logical, because vein rocks are formed on the postmagmatic stage of crystallization of siliceous intrusion. They may well contain noble metals which are typomorphic to these rocks. The temperature of formation of rare-metal pegmatites is about $500-650{ }^{\circ} \mathrm{C}$ (it decreases sharply in miarolas). This corresponds to the boundary PT-parameters $\left(\leq 500^{\circ} \mathrm{C}\right.$ and $\left.1-2 \mathrm{kbar}\right)$ for the medium of crystallization of native metals, which were determined by M. I. Novgorodova [18]. The absence of mineral concentrators (sulfides) in pegmatites completely explains the small size and high dispersion of precious metals.

\section{Acknowledgements}

The authors are grateful to the management of the Rezh state nature-mineralogical reserve ("Rezhevskoy") for the assistance in the research. The work was carried out as a part of the state budget theme "Paleogeodynamics and evolution of structural and material complexes in the formation of the Earth continental crust", № 0393-2016-0019.

\section{REFERENCES}

1. Zakharov A. V. 2017, Mineralogiya i tipizatsiya granitnykh pegmatitov Lipovskogo zhilnogo polya (Sredniy Ural) [Mineralogy and typing of granitic pegmatites from the Lipovskoye vein field (the Middle Urals)]. XVII Chteniya pamyati akademika A. N. Zavaritskogo. Sbornik statey [17 Readings in the memory of academician A. N. Zavaritsky. Collected papers]. Ekaterinburg, pp. 13-15.

2. Pekov I. V., Memetova L. R. 2008, Mineraly granitnykh pegmatitov Lipovki. Sredniy Ural [Minerals of the Lipovka granitic pegmatites in the Middle Urals]. $V$ mire mineralov. Mineralogicheskiy almanakh [The world of minerals. Mineralogical almanac], no. 13, pp. 7-44.

3. Erokhin, Yu. V., Zakharov A. V., Kaverina V. P. 2010, Samorodnyye metally (Au, Ag, Cu) iz granitnykh pegmatitov Lipovskogo zhilnogo polya (Sredniy Ural) [Native metals (Au, Ag, Cu) from granitic pegmatites of the Lipovskoye vein field (the Middle Urals)]. Ural'skaya mineralogicheskaya shkola-2010 [Ural mineralogical school-2010]. Ekaterinburg, pp. 58-60.

4. 1990, Mineralogiya Urala: elementy, karbidy, sulfidy [Mineralogy of the Urals: Elements. Carbides. Sulfides]. Sverdlovsk, $391 \mathrm{p}$.

5. Bykova E. Yu., Berlepsch P., Kartashov P. M., Brugger J., Armbruster T., Criddle A. J. 1989, Vergasovaite $\mathrm{Cu}_{3} \mathrm{O}\left[(\mathrm{Mo}, \mathrm{S}) \mathrm{O}_{4}\right]\left[\mathrm{SO}_{4}\right]$, a new copper-oxy-molybdate-sulfate from Kamchatka. Schweizerische Mineralogische und Petrographische Mitteilungen. 78, no. 6, pp. 479-488.

6. Mokhov A. V., Kartashov P. M., Bogatikov O. A., 2007, Luna pod mikroskopom: novyye dannyye po mineralogii Luny [The Moon under a microscope: new data on Mineralogy of the Moon]. Moscow, $127 \mathrm{p}$.

7. Popov V. A., Popova V. I. 2006, Mineralogiya pegmatitov IImenskikh gor [Mineralogy of the II'men mountains pegmatites]. Mineralogicheskiy almanakh. Assotsiatsiya Ekost [Mineralogical almanac. Ecost Association], vol. 9, 152 p.

8. Popova V. I., Popov V. A., Borshchev S. K., Demochkin V. P., Canonerov A. A. 1999, Mineralogiya granitnykh pegmatitov Alabashskogo polya samotsvetnoy polosy Urala [Mineralogy of granitic pegmatites of the Algabashskoye field in the semiprecious band of the Urals]. Miass, $90 \mathrm{p}$.

9. Tugarinov A. I., Bibikova E. V., Zykov S. I. 1964, O metamorfizme uranovykh mestorozhdeniy i otdelnykh uranovykh mineralov [On metamorphism of uranium deposits and separate uranium minerals]. Atomnaya energiya [Atomic energy], vol. 16, issue 4, pp. $332-343$.

10. Silayev V. I. Khazov A. F., Piskunov N. N. 2011, Otsenka mineralnykh mestorozhdeniy: khimiya. geokhimiya ili mineralogiya? [Evaluation of mineral deposits: Chemistry, Geochemistry or Mineralogy?]. Materialy V Rossiyskogo seminara po tekhnologicheskoy mineralogii «Mineralogo-tekhnologicheskaya otsenka mestorozhdeniy poleznykh iskopayemykh i problemy raskrytiya mineralov» [Proceedings of the Fifth Russian seminar on technological Mineralogy called "Mineralogical and technological assessment of mineral deposits and problems of mineral disclosure"]. Petrozavodsk, pp. 35-47.

11. Azovskova O. B., Rovnushkin M. Yu, Malyugin A.A. 2013, Gumeshevskoye mestorozhdeniye - ot drevnikh vremyon do nashikh dney [Gumeshevskoye field - from ancient times to the present day]. Uralskaya mineralogicheskaya shkola-2013. Materialy konferentsii [Ural mineralogical school-2013. Conference proceedings]. Ekaterinburg, pp. 12-18.

12. Vlasov K. A., Kutukova E. I. 1960, Izumrudnyye kopi [Emerald mines]. Moscow, 251 p.

13. Sustavov S. G., Popov M. P., Ogorodnikov V. N. 2014, Vismutovaya mineralizatsiya na Kvartalnom mestorozhdenii redkometalnykh pegmatitov (Sredniy Ural) [Bismuth mineralization at the Kvartal'noye Deposit of rare-metal pegmatites (Middle Urals)]. Vestnik Ural'skogo otdeleniya RMO [Bulletin of the Ural branch of the Russian Mineralogical Society]. Ekaterinburg, no. 11, pp. 98-104.

14. Mills S. J., Kartashov P. M., Kampf A. R., Rumsey M. S., Ma C., Spratt J., Rossman G. R., Novgorodova M. I. 2011, Tungsten, IMA $2011-004$. Mineralogical Magazine, vol. 75, pp. 2537-2542.

15. Novgorodova M. I., Nedashkovskaya N. H. Rasskazov A. V., Trubkin N. V. Semenov Ye. I., Koshelev B. L. 1995, Samorodnyy volfram s vklyucheniyami oksida ittriya iz allyuviya $r$. Bolshaya Polia (Pripolyarnyy Ural) [Native tungsten with inclusions of yttrium oxide from alluvium of the Bol'shaya Pol'ya river (Polar Urals)]. Doklady RAN [Doklady Earth Sciences], Vol. 340, no. 5, pp. 681-685.

16. Yang J., Meng F., Xu X., Robinson P. T., Dilek Y., Makeyev A. B., Wirth R., Wiedenbeck M., Griffin W. L., Cliff J. 2015, Diamonds, native elements and metal alloys from chromitites of the Ray-Iz ophiolite of the Polar Urals. Gondwana Research, vol. 27, № 2, pp. 459-485.

17. Glavatskikh S. F., Trubkin N. V. 2000, Pervyye nakhodki samorodnykh volframa i serebra v produktakh eksgalyatsiy Bolshogo treshchinnogo Tolbachinskogo izverzheniya (Kamchatka) [The first find of native tungsten and silver in the exhalation products of the Great fissure eruption of Tolbachik (Kamchatka)]. Doklady RAN [Doklady Earth Sciences], vol. 373, no. 4, pp. 523-526.

18. Novgorodova M. I. 1987, Samorodnyye metally [Native metals]. Moscow, 48 p. 


\title{
О находке золота, серебра, меди, свинца, висмута и вольсрама в пегматитах Аиповки (Средний Урах)
}

\author{
Анатолий Владимирович Захаров, \\ zakharov-zav@yandex.ru \\ Вера Витальевна Хиллер \\ hilvervit@mail.ru
}

\author{
Институт геологии и геохимии \\ им. академика А. Н. Заварицкого УрО РАН \\ Россия, Екатеринбург
}

\begin{abstract}
Актуамность работы обусловлена необходимостью более полного изучения минералогии редкометамьных гранитных пегматитов Аиповского жильного поля.

Цель работы: описание находки самородных метамлов (золота, серебра, меди, свинца, висмута и вольсррама) в гранитных пегматитах Аиповского жильного поля.

Методология исследования: детальное изучение химического состава, морсологии и взаимоотношения самородных метамов с минераиамиспутниками. Аля исследования отбирамись образцы из трех типов гранитных пегматитов - киассических кварц-полевошпатовых (в основном внутригранитных), Аесилицированных (апогранитных плагиокиазитов) и контаминированных митиеносных.

Результаты. В работе приводится описание самородных метамов (золота, серебра, меди, свинца, висмута и вольфрама), которые были обнаружены нами в редкометамьных пегматитах Аиповского жильного поля. Находка самородных метамов является первой на данном объекте. Микрозондовый анамиз таких самородных метамов, как золото и серебро, показаи изменчивость их химического состава от типа пегматита, в котором они находятся. Образование самородного свинца вполне ^огично связывать с разрушением и перекристамизацией высокоурановых цирконов, а формирование висмута и вольррама, возможно, произошло при перекристамизации акцессорных танталониобатов.

Выводы. Находка самородных метамов в гранитных пегматитах вполне объяснима, так как эти жильные породы фрормируются в постмагматическую стацию кристамизации кремнекислой интрузии и могут содержать типоморфные м^я этих пород метамы. Отсутствие в пегматитах минераловконцентраторов (сульридов) вполне объясняет мелкий размер и высокую рассеянность метамов.
\end{abstract}

Киючевые слова: самородные метамы; рудная минерамизация; гранитные пегматиты; Аиповское жильное поле; Средний Урал.

\section{ЛИТЕРАТУРА}

1. Захаров А. В. Минералогия и типизация гранитных пегматитов Липовского жильного поля (Средний Урал) // XVII Чтения памяти академика А. Н. Заварицкого: сборник статей. Екатеринбург: Ин-т геологии и геохимии УрО РАН, 2017. С. 13-15.

2. Пеков И. В., Меметова Л. Р. Минералы гранитных пегматитов Липовки, Средний Урал // В мире минералов. Минералогический альманax. 2008. № 13. С. 7-44

3. Ерохин Ю. В., Захаров А. В., Каверина В. П. Самородные металлы (Au, Ag, Cu) из гранитных пегматитов Липовского жильного поля (Средний Урал) // Уральская минералогическая школа-2010. Екатеринбург: Ин-т геологии и геохимии УрО РАН, 2010. С. 58-60.

4. Минералогия Урала: элементы, карбиды, сульфиды. Свердловск: УрО АН СССР, 1990. 391 с.

5. Bykova E. Yu., Berlepsch P., Kartashov P. M., Brugger J., Armbruster T., Criddle A. J. Vergasovaite $\mathrm{Cu}_{3} \mathrm{O}_{[}\left(\mathrm{Mo}_{\mathrm{O}} \mathrm{S}_{\mathrm{S}} \mathrm{O}_{4}\right]\left[\mathrm{SO}_{4}\right]$, a new cooper-oxymolybdate-sulfate from Kamchatka // Schweizerische Mineralogische und Petrographische Mitteilungen. 1989. Bd. 78, № 6. S. 479-488.

6. Мохов А. В., Карташов П. М., Богатиков О. А. Луна под микроскопом: новые данные по минералогии Луны. М.: Наука, 2007.127 с.

7. Попов В. А., Попова В. И. Минералогия пегматитов Ильменских гор: минералогич. альманах. Ассоциация Экост, 2006. Вып. 9.152 с.

8. Попова В. И., Попов В. А., Борщев С. К., Демочкин В. П., Канонеров А. А. Минералогия гранитных пегматитов Алабашского поля самоцветной полосы Урала. Миасс: Ин-т минералогии УрО РАН. 1999. 90 с.

9. Тугаринов А. И., Бибикова Е. В., Зыков С. И. О метаморфизме урановых месторождений и отдельных урановых минералов // Атомная энергия, 1964. Т. 16. Вып. 4. С. 332-343.

10. Силаев В. И., Хазов А. Ф., Пискунова Н. Н. Оценка минеральных месторождений: химия, геохимия или минералогия? // Минералого-технологическая оценка месторождений полезных ископаемых и проблемы раскрытия минералов: материалы $\mathrm{V}$ Рос. семинара по технологической минералогии. Петрозаводск: КНЦ РАН, 2011. С. 35-47.

11. Азовскова О. Б., Ровнушкин М. Ю., Малюгин А. А. Гумешевское месторождение - от древних времен до наших дней // Уральская минералогическая школа-2013: материалы конф. Екатеринбург: Ин-т геологии и геохимии УрО РАН, 2013. С. 12-18.

12. Власов К. А., Кутукова Е. И. Изумрудные копи. М.: Изд-во АН СССР, 1960. 251 с.

13. Суставов С. Г., Попов М. П., Огородников В. Н. Висмутовая минерализация на Квартальном месторождении редкометальных пегматитов (Средний Урал) // Вестник УрО РМО. 2014. № 11. С. 98-104.

14. Mills S. J., Kartashov P. M., Kampf A. R., Rumsey M. S., Ma C., Spratt J., Rossman G. R., Novgorodova M. I. Tungsten, IMA 2011-004 // Mineralogical Magazine. 2011. Vol. 75. P. 2537-2542.

15. Новгородова М. И., Недашковская Н. Н., Рассказов А. В., Трубкин Н. В., Семенов Е. И., Кошелев Б. Л. Самородный вольфрам с включениями оксида иттрия из аллювия р. Большая Полья (Приполярный Урал) // Докл. РАН, 1995. Т. 340, № 5. С. $681-685$.

16. Yang J., Meng F., Xu X., Robinson P. T., Dilek Y., Makeyev A. B., Wirth R., Wiedenbeck M., Griffin W. L., Cliff J. Diamonds, native elements and metal alloys from chromitites of the Ray-Iz ophiolite of the Polar Urals // Gondwana Research. 2015. Vol. 27, № 2. P. $459-485$.

17. Главатских С. Ф., Трубкин Н. В. Первые находки самородных вольфрама и серебра в продуктах эксгаляций Большого трещинного Толбачинского извержения (Камчатка) // Докл. РАН, 2000. Т. 373, № 4. С. 523-526.

18. Новгородова М. И. Самородные металлы. М.: Знание, 1987. 48 с. 